\title{
Jurnal Ilmu Kesehatan Masyarakat
} (The Public Health Science Journal)

Journal Homepage: http://journals.stikim.ac.id/index.php/jikm

\section{Analisis Penerapan Kurikulum Pendidikan Kesehatan Reproduksi Berbasis Program}

\author{
Ami Kamila ${ }^{1}$, Fatiah Handayani ${ }^{2}$, Nurhayati ${ }^{3}$ \\ ${ }^{1,2}$ Program Studi Sarjana Kebidanan dan Profesi Bidan, Universitas 'Aisyiyah Bandung \\ ${ }^{3}$ Program Studi Vokasi Diploma III Kebidanan, Universitas 'Aisyiyah Bandung \\ Jl. KH. Ahamd Dahlan Dalam No. 6, Lengkong, Kota Bandung \\ Email : bidankamila@gmail.com ${ }^{1}$, fatiah79@gmail.com ${ }^{2}$, nesa3364@gmail.com ${ }^{3}$
}

\begin{abstract}
Abstrak
Kurangnya pengetahuan remaja terkait kesehatan reproduksi masih menjadi permasalahan saat ini. Kelompok remaja seharusnya bisa disiapkan agar mampu menghadapi tantangan saat ini dan masa mendatang. Pendidikan kesehatan reproduksi yang terintegrasi dengan sistem pembelajaran di sekolah akan mampu menjangkau remaja yang diharapkan mampu untuk meningkatkan pengetahuan kesehatan reproduksi dan menghindari perilaku berisiko. Penelitian ini bertujuan untuk menganalisis rancangan dan efektivitas penerapan kurikulum kesehatan reproduksi berbasis program pada siswa SMP. Penelitian ini merupakan penelitian mixed methods dengan sequential explolatory designs untuk kualitatif dan Quasi experiment dengan one group pretest-posttest design untuk kuantitatif. Rancangan kurikulum disusun berdasarkan hasil analisis kebutuhan melalui Focus Group Discussion (FGD). Hasil FGD menunjukkan bahwa sekolah tidak memiliki rancangan pembelajaran khusus untuk pendidikan kesehatan reproduksi sebelumnya. Adapun yang sudah dilaksanakan merupakan program kesiswaan yang dikhususkan untuk siswi saja. Pendidik yang terlibat dalam program tersebut merupakan guru matematika dan biologi serta belum pernah mendapatkan pelatihan khusus terkait pembelajaran kesehatan reproduksi. Selama ini pembelajaran dilakukan dengan diskusi tanpa media gambar, sedangkan referensi yang dipakai adalah modul kesehatan reproduksi. Hasil analisa kuantitatif menunjukkan penerapan kurikulum pendidikan kesehatan reproduksi efektif dan memiliki pengaruh yang positif untuk meningkatkan pengetahuan siswa $(\mathrm{Pv}=0,000)$.
\end{abstract}

Kata Kunci: Kesehatan reproduksi remaja, kurikulum, pendidikan kesehatan.

\begin{abstract}
Lack of knowledge in adolescents regarding reproductive health is still a problem today. Youth groups are supposed to be prepared to be able to face current and future challenges. Reproductive health education integrated with the learning system in schools will be able to reach adolescents expected to be able to increase knowledge of reproductive health and avoid risky behavior. This study aims to analyze the design and effectiveness of the program-based reproductive health curriculum for junior high school students. This is a mixed method research with sequential explolatory designs for qualitative and a quasi experiment with one group pretest-posttest design for quantitative. The curriculum design is compiled based on the results of a needs analysis through a Focus Group Discussion (FGD). The results of the FGD indicated that schools did not have a special learning plan for reproductive health education before. While what had been implemented was a student program only for female students. The educators involved in the program are mathematics and biology teachers and have never received special training related to reproductive health learning. So far, learning was carried out by discussion without image media, while the reference used was the reproductive health module. The results of the quantitative analysis show that the implementation of the reproductive health education curriculum is effective and has a positive effect on increasing students' knowledge $(P v=0,000)$.
\end{abstract}

Keywords :Adolescent reproductive health, curriculum, health education. 


\section{Pendahuluan}

Hasil Survey Nasional Kesehatan Berbasis Sekolah di Indonesia menyebutkan bahwa kesehatan remaja usia sekolah SMP dan SMA menjadi bagian dari tujuan pembangunan berkelanjutan dalam menurunkan Angka Kematian Ibu dan Bayi (AKI dan AKB). ${ }^{1}$ Pendidikan tingkat SMP, SMA dan sektor kesehatan mengharapkan adanya identifikasi masalah perilaku berisiko di kalangan siswa dan program pencegahan yang tepat agar mampu meningkatkan kualitas belajar siswa. ${ }^{1}$

Berdasarkan hasil Survei Demografi Kesehatan Indonesia (SDKI), sebanyak 81\% remaja perempuan dan $84 \%$ remaja laki-laki telah berpacaran, $44 \%$ diantaranya baik remaja perempuan maupun laki-laki mulai berpacaran pada usia 15-17 tahun. Perilaku berpacaran remaja saat ini seperti berpegangan tangan, berciuman dan bersentuhan yang jika tidak diberikan pengetahuan yang cukup, akan mengarah pada perilaku seksual yang yang tidak aman dan berisiko. Sekitar $8 \%$ remaja laki-laki dan $2 \%$ remaja perempuan melakukan hubungan seksual pra nikah sejak usia 15 tahun. ${ }^{2}$ Permasalahan remaja yang berkaitan dengan perilaku seksual berisiko tersebut dipengaruhi oleh banyak faktor dan pengetahuan merupakan bagian penting dari faktor personal yang mempengaruhi perilaku seksual berisiko pada remaja. $^{3}$ Sejauh ini, pendidikan kesehatan reproduksi di Indonesia lebih fokus pada aspek biologis dan pencegahan penyakit menular. ${ }^{4}$

Kurangnya informasi dan pengetahuan khususnya terkait kesehatan reproduksi pada remaja masih menjadi permasalahan kesehatan pada remaja saat ini. Hasil penelitian Ratnawati menunjukkan bahwa pengetahuan siswa masih sangat kurang mengenai kesehatan reproduksi dan seksual pranikah. ${ }^{5}$ Kurangnya personal hygiene pada siswa dan siswi yang merupakan salah satu aspek kesehatan reproduksi yang harus dimiliki remaja berhubungan dengan kurangnya keterpaparan informasi. ${ }^{6}$ Pendidikan kesehatan reproduksi dan seksualitas masih dianggap hal yang tabu tetapi penting untuk dibicarakan dan terdapat kekhawatiran jika hal ini bisa membuat remaja ingin mengetahui dan mendorong berperilaku seks pranikah. ${ }^{7}$ Fakta menunjukkan, pendidikan kesehatan reproduksi belum menjangkau seluruh remaja dan lebih banyak dilakukan di komunitas atau organisasi agama dan pemuda dan keterbatasan lainnya serta hampir tidak ada keberlanjutan program kesehatan reproduksinya. $^{7}$

Kurikulum berbasis program ini merupakan penekanan definisi yang dituliskan oleh undang-undang yang berlaku dengan dilandasi pada program yang dibuat untuk mencapai tujuan tertentu. Penelitian sebelumnya sebagian besar menitikberatkan pada hubungan dan pengaruh pendidikan kesehatan reproduksi remaja pada peningkatan pengetahuan, sikap dan perilaku remaja. Namun belum ditemukan hasil penelitian yang komprehensif mulai dari awal analisa kebutuhan, merancang kurikulum dan analisa pengaruhnya. Beberapa penelitian sebelumnya dijadikan landasan utama penelitian lanjutan tentang analisis penerapan kurikulum pendidikan kesehatan reproduksi berbasis program di SMP Kabupaten Bandung.

Tujuan penelitian ini secara umum untuk merancang kurikulum pendidikan kesehatan reproduksi sesuai kebutuhan dan menganalisis efektivitas rancangan dan penerapan kurikulum kesehatan reproduksi berbasis program kepada siswa/i di SMP Kabupaten Bandung. Hasil dari penelitian ini diharapkan mampu mewujudkan rancangan kurikulum pendidikan kesehatan reproduksi berbasis program yang dapat digunakan untuk tingkat SMP.

\section{Metode}

Penelitian ini merupakan penelitian mixed methods dengan model kombinasi sequential exploratory designs, dimana peneliti melakukan pengumpulan data sebagai analisis kebutuhan dan dasar merancang kurikulum kesehatan reproduksi berbasis program dengan metode kualitatif. 
Sedangkan untuk penelitian kuantitatif, menggunakan Quasi Experiment dengan one group pretest-posttest design. Pengambilan sampel dilakukan dengan purposive sampling sebanyak 20 orang siswa dan group diskusi terdiri dari 8 orang. Penelitian dilakukan secara blended, baik luring maupun daring dengan menggunakan zoom meeting conference karena situasi pandemi Covid-19 dalam rentang waktu September - November 2020.

Teknik pengumpulan data berupa Focus Group Discussion (FGD) kepada pemangku kebijakan dan pendidik yang terlibat dalam pendidikan kesehatan reproduksi di SMP Muhammadiyah 4 Margahayu Kabupaten Bandung. Kemudian melakukan penelitian dengan metode kuantitatif untuk melakukan uji coba rancangan kurikulum kepada siswa, peneliti menggunakan penelitian Quasi Experiment one group pretest-posttest design.

Data yang diambil pada metode kuantitatif adalah hasil pre-test dan post-test yang diberikan kepada siswa SMP untuk mengetahui adanya pengaruh penerapan kurikulum pendidikan kesehatan reproduksi remaja pada siswa. Selanjutnya, peserta program diberikan angket yang akan diteliti secara deskriptif untuk mengetahui sejauh mana efektivitas penerapan kurikulum pada peserta. Instrumen yang digunakan berupa pedoman berisi prosedur dan daftar pertanyaan sesuai tujuan penelitian yang dilakukan saat FGD dan soal tes yang diberikan saat pre-test dan post-test. Sedangkan instrumen non tes yang digunakan adalah angket mengenai efektifitas penerapan kurikulum berbasis program pada pendidikan kesehatan reproduksi remaja. Angket yang digunakan merupakan modifikasi dari angket pada penelitian yang sudah dilakukan Yulianti mengenai Efektivitas Penerapan Kurikulum Tingkat Satuan Pendidikan (KTSP). ${ }^{8}$

Analisis data pada metode kualitatif dilakukan dengan data reduction, data display dan conclusion drawing/verification. Perolehan data dari kualitatif selanjutnya dianalisa untuk perumusan kurikulum berbasis program pada pendidikan kesehatan reproduksi remaja sehingga kurikulum akan sesuai dengan kebutuhan yang diharapkan. Sedangkan pada analisa data kuantitatif hasil dari pretest dan posttest dilakukan untuk menguji persyaratan analisis hipotesis yaitu uji normalitas dan uji homogenitas, kemudian dilakukan dengan uji hipotesis untuk melihat perbedaan hasil belajar dari penerapan kurikulum berbasis program pada pendidikan kesehatan remaja ini. Uji normalitas data menggunakan Kolmogorov-Smirnov Test.

Pada uji homogenitas, menggunakan statistik uji Levene Test (test of Homogenity of Variance) dimana data dikatakan homogen jika nilai signifikansi lebih besar dari $\alpha(\alpha=0,05)$.(9) Setelah uji normalitas dan homogenitas, untuk menguji hipotesis maka data dianalisis dengan uji $t$ ( $t$-test).

\section{Hasil}

Peserta Focus Group Discussion berjumlah 8 orang beserta tim peneliti, 5 diantaranya merupakan pemegang kebijakan, pengelola, pendidik dan pelaksana kurikulum di SMP Muhammadiyah 4 Margahayu. Siswa yang terlibat dalam penelitian sebanyak 20 orang dengan sebagian besar diantaranya $(65 \%)$ berjenis kelamin perempuan dan berusia 14 tahun (60\%) (Tabel 1). Tim peneliti memilih informan sebagai peserta FGD berdasarkan fungsi dan perannya serta yang berkepentingan sebagai analisa kebutuhan dan dasar penyusunan Rancangan Kurikulum Berbasis Program untuk Pendidikan Kesehatan Reproduksi di sekolah ini (Tabel 2).

Tabel 1. Karakteristik Responden Siswa/i SMP

\begin{tabular}{llcc}
\hline \multicolumn{1}{c}{ Karakteristik } & Kategori & n & \% \\
\hline Usia & 13 tahun & 8 & 40 \\
& 14 tahun & 12 & 60 \\
Jenis Kelamin & Laki-laki & 7 & 35 \\
& Perempuan & 13 & 65 \\
Agama & Islam & 20 & 100 \\
& Lain-lain & 0 & 0 \\
Tempat Tinggal & Bandung & 20 & 100 \\
& Lain-lain & 0 & 0 \\
\hline
\end{tabular}


Tabel 2. Karakteristik/ Profil Informan Peseta FGD

\begin{tabular}{|c|c|c|c|}
\hline No & Inisial & Pekerjaan & Fungsi dan Peran \\
\hline 1 & $\mathrm{AgS}$ & Kepala Sekolah & $\begin{array}{l}\text { Sebagai penyusun rencana, pengelola program, pengelola sumber } \\
\text { daya, sarana dan prasarana serta pengelola pengembangan } \\
\text { kurikulum dan kegiatan belajar di sekolah. Selain itu, kepala } \\
\text { sekolah berperan dalam mengawasi kegiatan program yang } \\
\text { disusun, baik oleh sendiri maupun didelegasikan kepada yang } \\
\text { berwenang dan memberikan dukungan serta fungsi sosial baik } \\
\text { kepada pendidik maupun peserta didik. }\end{array}$ \\
\hline 2 & $\mathrm{RN}$ & $\begin{array}{l}\text { Penanggungjawab } \\
\text { Program }\end{array}$ & $\begin{array}{l}\text { Sebagai pengelola sekaligus pendidik pada program keputerian } \\
\text { atau pendidikan kesehatan reproduksi di sekolah. }\end{array}$ \\
\hline 3 & AiS & Bidang Kurikulum & $\begin{array}{l}\text { Menyusun dan mengkoordinir program pengajaran, } \\
\text { bertanggungjawab melakukan monitoring dan evaluasi terhadap } \\
\text { pelaksanaan program pengajaran serta mengawasi kesesuaian } \\
\text { kurikulum dan bahan ajar yang telah berlaku, mendokumentasikan } \\
\text { data serta informasi terkait pelaksanaan kurikulum di sekolah. }\end{array}$ \\
\hline 4 & LM & Bidang Kesiswaan & $\begin{array}{l}\text { Menyusun, mengoordinir dan mengawasi pelaksanaan program } \\
\text { kerja kegiatan sekolah dibidang kesiswaan, melakukan monitoring } \\
\text { dan evaluasi serta mendokumentasikan data dan informasi terkait } \\
\text { kegiatan kesiswaan di sekolah. }\end{array}$ \\
\hline 5 & NL & Pendidik & $\begin{array}{l}\text { Sebagai salah satu pendidik pada program keputrian, bersama } \\
\text { dengan RN memberikan pendidikan kesehatan reproduksi remaja } \\
\text { dari berbagai media. }\end{array}$ \\
\hline
\end{tabular}

Sebelum melakukan analisa kualitatif, tim peneliti melakukan analisa SWOT melalui observasi dan hasil penelitian di tempat yang sama pada tahun sebelumnya. Analisis SWOT yang telah dilakukan dapat dilihat pada matriks berikut :

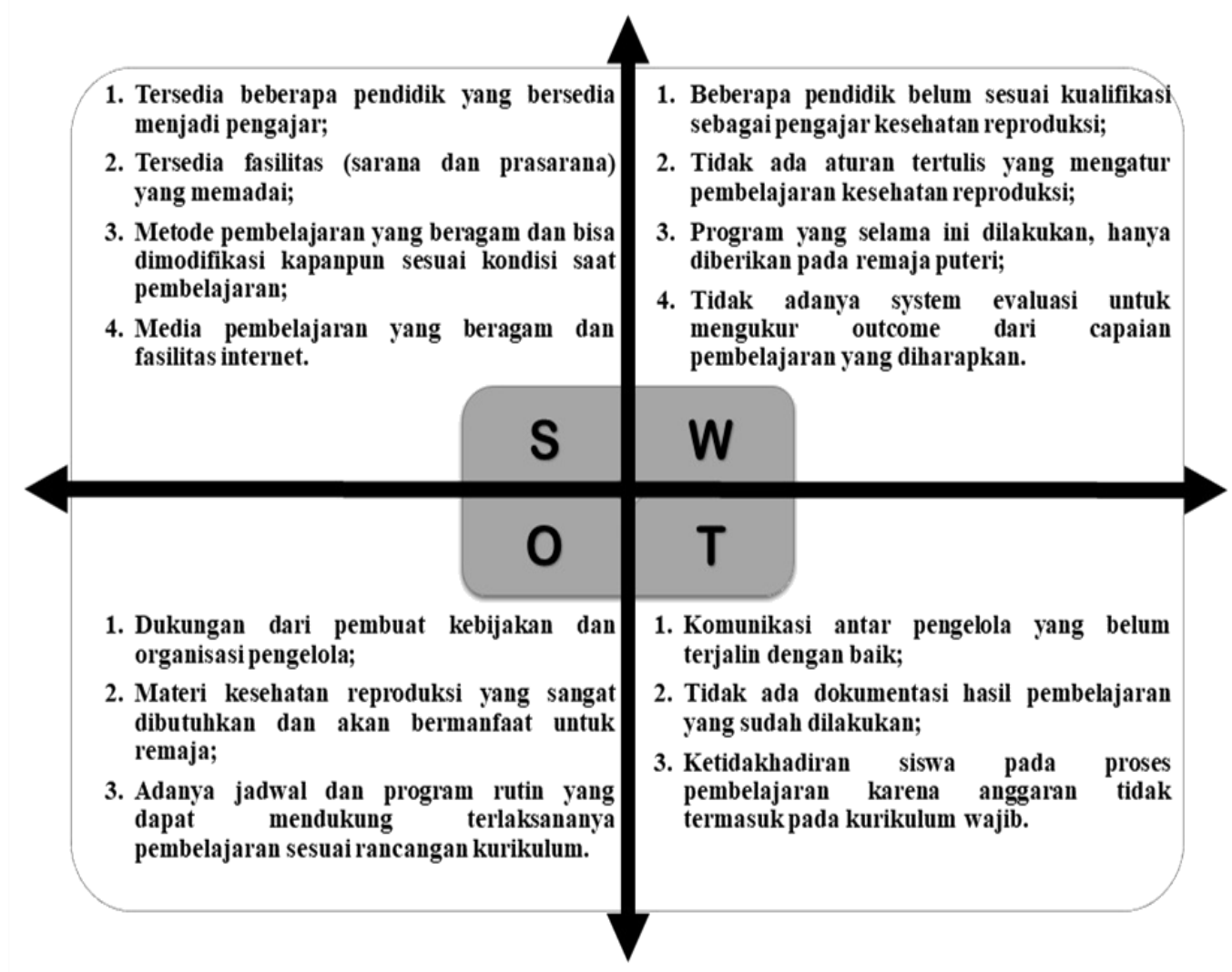

Gambar 1. Matriks Analisa SWOT (Strengts, Weakness, Opportunity, Threat) 
Beberapa hal yang menjadi bahan diskusi saat melakukan FGD merupakan indikator yang harus ada pada rancangan kurikulum yang akan disusun. Hasil FGD akan dipaparkan melalui tabel matriks berikut :

Tabel 3. Matriks Hasil Focus Group Discussion (FGD)

\begin{tabular}{|c|c|}
\hline Indikator & Kesimpulan \\
\hline $\begin{array}{l}\text { Rancangan Belajar } \\
\text { Rancangan pembelajaran yang sudah ada atau } \\
\text { yang diharapkan? } \\
\text { Fasilitas khusus untuk pembelajaran untuk } \\
\text { seluruh siswa/i sesuai jadwal? }\end{array}$ & $\begin{array}{l}\text { 1. Tidak ada rancangan pembelajaran khusus untuk } \\
\text { pembelajaran kesehatan reproduksi sebelumnya; } \\
\text { 2. Pembelajaran dilakukan secara spontan sesuai dengan } \\
\text { jadwal program keputerian setiap minggunya; } \\
\text { 3. Tidak ada fasilitas khusus, namun sarana dan prasarana } \\
\text { sudah memadai untuk melaksanakan pembelajaran } \\
\text { kesehatan reproduksi. }\end{array}$ \\
\hline $\begin{array}{l}\text { Media dan Materi Pembelajaran } \\
\text { Alternatif media untuk memudahkan siswa/i } \\
\text { memahami materi? } \\
\text { Materi pembelajaran yang ingin diberikan } \\
\text { pada siswa/i? }\end{array}$ & $\begin{array}{l}\text { 1. Modul bergambar, video, slide powerpoint, media yang } \\
\text { interaktif; } \\
\text { 2. Kesehatan Reproduksi Remaja, ditambah dengan } \\
\text { penyimpangan seksual dengan kasus-kasus yang ada. }\end{array}$ \\
\hline $\begin{array}{l}\text { Proses Pembelajaran } \\
\text { Motivasi belajar siswa/i mengikuti } \\
\text { pembelajaran Kesehatan Reproduksi yang } \\
\text { sudah ada? } \\
\text { Metode pembelajaran yang dapat digunakan? }\end{array}$ & $\begin{array}{l}\text { 1. Motivasi belajar baik, dapat dilihat dari kehadiran siswa } \\
\text { yang lebih dari } 90 \% \text { setiap minggunya; } \\
\text { 2. PAKEM : Pembelajaran Aktif, Kreatif, Efektif, dan } \\
\text { Menyenangkan. }\end{array}$ \\
\hline $\begin{array}{l}\text { Metode Penilaian } \\
\text { Bagaimana metode penilaian yang diinginkan } \\
\text { dan akan dirancang? }\end{array}$ & $\begin{array}{l}\text { Tanya jawab, pre-posttest, mengisi quiz atau evaluasi yang } \\
\text { tersedia pada setiap akhir masing-masing materi pada modul. }\end{array}$ \\
\hline $\begin{array}{l}\text { Evaluasi } \\
\text { Evaluasi pembelajaran Kesehatan Reproduksi } \\
\text { yang sudah ada? } \\
\text { Metode evaluasi yang akan digunakan? }\end{array}$ & $\begin{array}{l}\text { 1. Tidak ada evaluasi pembelajaran kesehatan reproduksi } \\
\text { sebelumnya; } \\
\text { 2. Benchmarking untuk mengukur kinerja, kesesuaian } \\
\text { perencanaan, proses dan outcome yang dihasilkan. }\end{array}$ \\
\hline
\end{tabular}

Tabel 4. Contoh Kompetensi Inti dan Kompetensi Dasar Pendidikan Kesehatan Reproduksi Remaja

\begin{tabular}{|c|c|}
\hline Standar Kompetensi & Kompetensi Dasar \\
\hline \multirow{4}{*}{$\begin{array}{l}\text { Memahami dan menerapkan pengetahuan } \\
\text { (faktual, konseptual dan prosedural) berdasarkan } \\
\text { rasa ingin tahu tentang ilmu pengetahuan, } \\
\text { teknologi, seni, budaya terkait fenomena dan } \\
\text { kejadian tampak mata }\end{array}$} & $\begin{array}{l}\text { Memahami konsep gaya hidup sehat untuk } \\
\text { mencegah berbagai penyakit; }\end{array}$ \\
\hline & $\begin{array}{l}\text { Memahami prinsip-prinsip pencegahan terhadap } \\
\text { bahaya seks bebas, NAPZA, dan obat berbahaya } \\
\text { lainnya, bagi diri sendiri, keluarga dan masyarakat; }\end{array}$ \\
\hline & Memahami pola makan sehat, bergizi dan seimbang; \\
\hline & Memahami kenakalan remaja. \\
\hline
\end{tabular}

Sumber: Buku Rancangan Kurikulum Pendidikan Kesehatan Reproduksi Remaja Berbasis Kasus ${ }^{1}$

Contoh Standar kompetensi dan Kompetensi Dasar serta Rancangan Pembelajaran Kesehatan Reproduksi Remaja pada rancangan kurikulum yang telah disusun berdasarkan hasil analisa kebutuhan penelitian kualitatif terlihat pada tabel 4.

Berdasarkan penelitian yang dilakukan secara Quasi Eksperimen dengan one group pre-posttest design, data deskripsi efektivitas penerapan kurikulum pendidikan kesehatan reproduksi berbasis program menggambarkan bahwa sebagian besar siswa $(60 \%)$ menyatakan setuju penerapan kurikulum (berbasis program) diperlukan dalam pembelajaran kesehatan reproduksi di sekolah termasuk didalamnya setuju dalam semua indikator yang dibutuhkan dalam penerapan kurikulum di sekolah.

Selanjutnya data kecenderungan efektifitas penerapan kurikulum kespro berbasis program disusun dalam bentuk 
frekuensi yang disajikan dalam tabel 6 . Kecenderungan efektifitas penerapan kurikulum kespro berbasis program menyatakan tinggi yakni sebanyak 8 orang (40\%) (Tabel 6).

Pengujian hipotesis untuk mengetahui efektivitas penerapan kurikulum dalam meningkatkan pengetahuan siswa, maka dilakukan uji beda dengan uji T-test. Uji ini dilakukan untuk menguji nilai rata-rata pre dan post test pada kelompok yang diteliti dengan menggunakan bantuan IBM SPSS Statistics 20.0 for windows. Berdasarkan tabel di atas $\mathrm{p}$ value menunjukkan hasil $0,000 \leq 0,05$, maka hasilnya dapat dikatakan signifikan, artinya bahwa ada pengaruh yang positif dan signifikan antara efektivitas penerapan kurikulum kesehatan reproduksi terhadap pengetahuan siswa di SMP Muhammadiyah 4 (Tabel 6).

Tabel 5. Contoh Rancangan Pembelajaran Pendidikan Kesehatan Reproduksi Remaja

\begin{tabular}{|c|c|c|c|c|c|}
\hline $\begin{array}{c}\text { Kompetensi } \\
\text { Dasar }\end{array}$ & Materi Pokok & Indikator & $\begin{array}{l}\text { Kegiatan } \\
\text { Belajar }\end{array}$ & Penilaian & $\begin{array}{l}\text { Sumber } \\
\text { Belajar }\end{array}$ \\
\hline $\begin{array}{l}\text { Mampu } \\
\text { menjelaskan dan } \\
\text { memahami } \\
\text { kenakalan pada } \\
\text { remaja sehingga } \\
\text { mampu } \\
\text { menghindari } \\
\text { perilaku tersebut }\end{array}$ & $\begin{array}{l}\text { Pengertian } \\
\text { kenakalan } \\
\text { remaja; } \\
\text { Penyebab } \\
\text { kenakalan } \\
\text { remaja; } \\
\text { Bentuk-bentuk } \\
\text { kenakalan } \\
\text { remaja; } \\
\text { Kenakalan } \\
\text { remaja dalam } \\
\text { pandangan } \\
\text { islam; } \\
\text { Analisis solusi } \\
\text { kenakalan } \\
\text { remaja. }\end{array}$ & 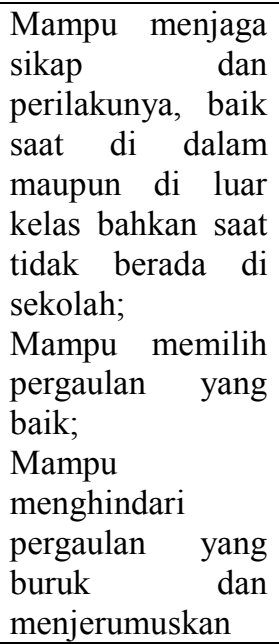 & $\begin{array}{l}\text { Guru memutar } \\
\text { video kenakalan } \\
\text { remaja; } \\
\text { Memberikan } \\
\text { contoh kasus; } \\
\text { Diskusi terkait } \\
\text { pemecahan } \\
\text { masalah yang } \\
\text { baik. }\end{array}$ & $\begin{array}{l}\text { Teknik: } \\
\text { Quiz; } \\
\text { Tes tulis; } \\
\text { Lisan; } \\
\text { Instrument : } \\
\text { Latihan modul } \\
\text { Sikap : } \\
\text { Dilihat dari } \\
\text { sikap dan } \\
\text { perilaku siswa } \\
\text { yang tidak } \\
\text { melakukan } \\
\text { kenakalan } \\
\text { remaja }\end{array}$ & $\begin{array}{l}\text { Modul } \\
\text { KRR untuk } \\
\text { pengajar } \\
\text { dan siswa; } \\
\text { Referensi } \\
\text { terkait } \\
\text { kenakalan } \\
\text { remaja } \\
\text { (video/ } \\
\text { foto). }\end{array}$ \\
\hline
\end{tabular}

Tabel 6. Kecenderungan Penerapan Kurikulum Pendidikan Kesehatan Reproduksi

\begin{tabular}{llll}
\hline \multicolumn{1}{c}{ Skor } & \multicolumn{1}{c}{ Kategori } & n & \% \\
\hline$>89,34$ & Sangat Tinggi & 3 & 15 \\
$83,09-89,34$ & Tinggi & 8 & 40 \\
$76,84-83,09$ & Sangat Rendah & 2 & 10 \\
$<76,84$ & Sangat Rendah & 2 & 10 \\
\hline
\end{tabular}

Tabel 7. Hasil Uji T Test Kurikulum Terhadap Pengetahuan Siswa

\begin{tabular}{lccccc}
\hline & n & Rerata + s.b & Perbedaan Rerata \pm s.b & IK 95\% & $\boldsymbol{p}$ \\
\hline Pre Intervensi & 20 & $60,01 \pm 11,28$ & $18,16 \pm 13,52$ & $24,48-11,83$ & 0,000 \\
Post Intervensi & 20 & $78,16 \pm 7,05$ & & & \\
\hline
\end{tabular}

\section{Pembahasan}

Berdasarkan hasil analisa kebutuhan melalui FGD, langkah untuk merancang kurikulum pendidikan kesehatan reproduksi untuk siswa/i SMP dengan berbasis program ini dilakukan dengan cara : (1) Melakukan analisis kemampuan potensi yang dimiliki pendidik; (2) Melakukan analisis fasilitas belajar yang tersedia di sekolah; dan (3) Melakukan kajian dan perumusan standar kompetensi siswa yang sesuai dengan capaian pembelajaran.

Sesuai dengan hasil observasi dan FGD, pendidik yang selama ini aktif dalam program keputerian atau pendidikan kesehatan reproduksi merupakan guru 
matematika dan biologi. Walaupun belum sesuai dengan kualifikasi untuk menjadi pendidik pada kesehatan reproduksi, namun selama ini selalu berusaha memberikan pelajaran terkait kesehatan reproduksi dengan metode diskusi tanya jawab dibantu dengan pengetahuan dari buku atau internet. Sesuai dengan hasil penelitian yang dilakukan secara kualitatif di sekolah yang sama, bahwa sumberdaya manusia sebagai pendidik dan pengelola program pendidikan kesehatan reproduksi belum memadai dan belum mempunyai pendidik yang berlatarbelakang pendidikan kesehatan sehingga selama ini implementasi program diserahkan kepada guru matematika dan biologi.

Menurut Hollis L. Caswell dan Campbell, menyatakan bahwa : “... all of the experiences children have under guidance of teacher" yang berarti semua pengalaman yang dimiliki anak-anak di bawah bimbingan guru. Pendapat ini menunjukkan, bahwa kurikulum bukan hanya tentang mata pelajaran, namun menyangkut usaha pendidik untuk mampu mempengaruhi siswa belajar guna mencapai tujuan pembelajaran. Guru sebagai pendidik dituntuk untuk selalu kreatif, inovatif, profesional dan mampu mengikuti perkembangan teknologi berkaitan dalam dunia pendidikan. Bukan hanya didukung oleh kurikulum yang sesuai, namun kemampuan pendidik untuk menyampaikan pelajaran yang sesuai dengan kurikulum juga menjadi kunci untuk mencapai prestasi belajar siswa. ${ }^{12}$

Fasilitas yang ada di sekolah saat ini dirasa memadai untuk melaksanakan program pendidikan kesehatan pada siswanya, walaupun belum disediakan fasilitas khusus sebagai tempat yang akan digunakan secara rutin. Menurut pendapat Saylor dan Alexander, kurikulum bukan hanya tentang mata pelajaran, namun terkait seluruh usaha sekolah untuk memfasilitasi bahkan memengaruhi siswa agar mempunyai motivasi belajar, baik di dalam maupun di luar kelas bahkan saat tidak berada di sekolah. ${ }^{13}$ Hal ini juga sesuai dengan hasil penelitian yang menyebutkan bahwa fasilitas belajar memiliki hubungan positif yang signifikan dengan motivasi belajar dan hasil belajar yang ditunjukkan dengan keaktifan dan ketertarikan siswa saat proses pembelajaran menggunakan media seperti video, gambar dan alat peraga. ${ }^{14}$

Beberapa landasan sebagai dasar penyusunan kurikulum ini diantaranya adalah yang pertama Landasan Yuridis, dimana kesehatan reproduksi remaja menjadi salah satu fokus pemerintah untuk mencapai tujuan pembangunan nasional, karena generasi sehat akan melahirkan generasi sehat selanjutnya. Landasan yuridis tersebut tercantum pada Peraturan Pemerintah RI Nomor 61 Tahun 2014 tentang Kesehatan Reproduksi dimana pada pasal 12 menyatakan bahwa pelayanan KRR dilaksanakan melalui Komunikasi, Informasi dan Edukasi serta diperjelas pada poin (5) yaitu pemberian materi komunikasi, informasi dan edukasi dilaksanakan melalui proses pendidikan formal dan nonformal serta kegiatan pemberdayaan remaja sebagai pendidik sebaya atau konselor sebaya. ${ }^{15}$ Landasan yang kedua yaitu Landasan Filosofis, dimana pelayanan kesehatan reproduksi remaja adalah suatu kegiatan yang ditujukan kepada remaja dalam rangka menjaga kesehatan reproduksi. Landasan yang ketiga yaitu Landasan Teoritis, tertuang dalam Peraturan Pemerintah RI Nomor 61 Tahun 2014 tentang ruang lingkup materi kesehatan reproduksi.

Rancangan pembelajaran disusun berdasarkan analisa kebutuhan melalui FGD, bersifat PAKEM yaitu pembelajaran aktif, kreatif, efektif dan menyenangkan. Pembelajaran tidak harus formal seperti di dalam kelas, namun tetap disiplin dan menghargai guru sebagai fasilitator. Pembelajaran dengan menggunakan pendekatan Student Centered Learning (SCL) dimana peserta didik berperan aktif dalam pembelajaran dengan diskusi dan berbasis kasus sehingga diharapkan mereka mampu memecahkan masalah secara mandiri. Kasus yang diberikan merupakan gambaran kejadian yang seringkali terjadi 
dalam kehidupan bermasyarakat. Berdasarkan penelitian Lala Lubana, dkk terkait pengambangan perangkat pembelajaran berbasis kasus dan berorientasi pendidikan karakter, menunjukkan hasil bahwa perangkat pembelajaran berbasis kasus tersebut valid dan memiliki pengaruh pada hasil belajar, aspek kognitif dan afektif peserta didik. ${ }^{16}$

Pembelajaran dengan pendekatan SCL dengan metode Problem Based Learning (PBL), mampu mendorong peserta didik untuk aktif dalam memecahkan masalah yang sederhana selama pembelajaran. Metode ini juga mampu membentuk kemampuan dan keterampilan (thinking skills) sebagai bekal untuk hidup mandiri dan pembelajaran sepanjang hayat (lifelong learning). Sejalan dengan penelitian Jun Jin dan Susan M Bridges yang menunjukkan hasil positif pada pembelajaran siswa dengan menggunakan metode PBL. Hal ini akan dapat mengambangkan pengetahuan dan keterampilan untuk kolaborasi atau diskusi. $^{17}$ Penelitian lain yang membandingkan antara pembelajaran klasik seperti ceramah dan PBL dilakukan oleh Rizwan Faisal, et al membuktikan bahwa pembelajaran berbasis kasus lebih efektif dibandingkan dengan metode ceramah dalam kinerja akademik peserta didik. ${ }^{18}$

Berdasarkan hasil analisa uji t-test, menunjukkan ada pengaruh positif dan signifikan antara efektivitas penerapan kurikulum kesehatan reproduksi terhadap pengetahuan siswa. Penelitian tentang Implementasi kurikulum, dilakukan oleh O Kurniawan dan Lazim N di Pekanbaru menunjukkan penilaian hasil belajar pada siswa yang meningkat, walaupun ada beberapa aspek yang belum dilakukan secara baik oleh pendidik seperti penilaian dan pelaksanaan pembelajaran. ${ }^{19}$ Penelitian lain dilakukan oleh Ainna Khoiron Nawali, walaupun dengan kurikulum yang berbeda namun yang dibandingkan adalah dampak dan pencapaiannya terhadap hasil belajar, menunjukkan hasil yang dan dampak yang positif. Kelebihan dari penerapan kurikulum yang diimplementasikan secara baik, akan berpengaruh pada siswa untuk menguasai materi dan meningkatkan nilai ujian. ${ }^{20}$

Analisis penerapan kurikulum yang dilakukan Ina Magdalena, dkk menunjukkan bahwa penerapan kurikulum terbukti mampu meningkatkan hasil belajar siswa pada arah yang positif, hal ini tampak dari hasil tes yang telah dilakukan. ${ }^{21}$ Menurut Sanjaya, kurikulum dan pembelajaran seperti dua sisi mata uang logam yang tidak dapat dipisahkan dan sama-sama memiliki peranan penting serta keterkaitan satu sama lain. Fungsi kurikulum sebagai pedoman dalam melaksanakan proses pembelajaran dan harus dievaluasi untuk mengetahui output pembelajaran dengan melakukan penilaian. Penilaian ini bermanfaat untuk menjamin supaya proses pembelajaran diarahkan untuk mencapai kompetensi tertentu yang terdapat pada kurikulum. Selain itu, penilaian juga dilakukan sebagai analisis kelemahan yang akan menjadi dasar perbaikan proses pembelajaran menjadi efektif dan efisien. Penilaian sebaiknya dilakukan secara terbuka dengan harapan meningkatkan motivasi belajar dan mereka dapat memahami posisinya dalam pencapaian kompetensi. ${ }^{13}$

Menurut Tyler dalam Albaar menyatakan "is the process for determining the degree to which these change in behavior are actually taking place". Evaluasi berfokus pada upaya untuk meningkatkan perubahan yang terjadi pada hasil belajar (behavior). Hasil dari evaluasi yang telah dilakukan akan digunakan dan diperlukan saat analisa data pencapaian yang telah dan perbaikan yang akan dilakukan selanjutnya. ${ }^{22}$ Evaluasi model Context, Input, Process and Product (CIPP) merupakan model evaluasi yang ditawarkan oleh Stufflebeam adalah suatu rangkaian yang saling berurutan dan berkesinambungan. Konsep tersebut berpandangan bahwa tujuan penting dari evaluasi bukan untuk membuktikan namun untuk memperbaiki. ${ }^{23}$

\section{Kesimpulan}

Berdasarkan hasil penelitian kualitatif, rancangan kurikulum disusun berdasarkan 
hasil analisa kebutuhan dengan 3 langkah, yaitu melakukan analisis kemampuan potensi yang dimiliki pendidik, analisis fasilitas belajar yang tersedia di sekolah dan melakukan kajian dan perumusan standar kompetensi siswa yang sesuai dengan capaian pembelajaran. Berdasarkan hasil penelitian kuantitatif, dapat disimpulkan bahwa rancangan kurikulum pendidikan kesehatan reproduksi berbasis program untuk siswa SMP terbukti efektif untuk meningkatkan pengetahuan melalui pembelajaran.

\section{Saran}

Pihak sekolah diharapkan dapat menyempurnakan dan menerapkan rancangan kurikulum serta melanjutkan pembelajaran yang telah dilakukan saat penelitian untuk meningkatkan pengetahuan terkait kesehatan reproduksi pada remaja di sekolah. Keterbatasan dari penelitian ini adalah belum menggali lebih jauh terkait ketersediaan sumber daya pengajar di sekolah dan pengaruhnya terhadap peningkatan pengetahuan kesehatan reproduksi melalui pembelajaran. Oleh karena itu, untuk penelitian selanjutnya diharapkan mampu menggali pengaruh sumber daya khususnya pendidik terhadap peningkatan pengetahuan siswa sehingga bisa dicari alternatif solusi seperti pelatihan untuk pendidik di sekolah.

\section{Ucapan Terima Kasih}

Ucapan terimakasih peneliti disampaikan kepada semua pihak yang telah membantu proses pelaksanaan sampai penyelesaian penelitian ini, kepada Kementerian Riset dan Teknologi/Badan Riset dan Inovasi Nasional Republik Indonesia sebagai pemberi dana penelitian ini. Kami juga ucapkan terimakasih kepada SMP Muhammadiyah 4 Margahayu Kabupaten Bandung yang telah memberikan kepercayaan, kesempatan dan mengizinkan kami untuk melakukan penelitian dan pengambilan data. Akhir kata, kami mengucapkan terimakasih kepada semua pihak dan rekan di Universitas 'Aisyiyah
Bandung atas dukungan dan motivasinya.

\section{Daftar Pustaka}

1. Kusumawardani N, dkk. Perilaku Berisiko Kesehatan Pada pelajar SMP dan SMA di Indonesia [Internet]. Puslitbang Upaya Kesehatan Masyarakat. Jakarta: Badan Litbangkes Kementerian Kesehatan RI; 2015. Available from: https://www.who.int/ncds/surveillance/gshs/GS HS_2015_Indonesia_Report_Bahasa.pdf

2. BKKBN. Survei demografi dan kesehatan Indonesia 2017: Kesehatan reproduksi remaja. Badan Kependudukan dan Keluarga Berencana Nasional. Jakarta, Indonesia; 2018.

3. Cherry AL, Baltag V, Dillon ME. International handbook on adolescent health and development. Public Heal Response Switz Springer Int Publ. 2016;

4. Fitriana $\mathrm{H} \&$ Siswantara P. Pendidikan Kesehatan Reproduksi Remaja di SMPN 52 Surabaya. The Indonesia Journal of Public Health. 2018;13(1):107-18.

5. Ratnawati R. Pengaruh Promosi Kesehatan dengan Metode Ceramah Tentang Kesehatan Reproduksi Terhadap Pengetahuan dan Sikap Remaja Tentang Seks Pranikah. VISIKES Jurnal Kesehatan Masyarakat. 2020;19(2).

6. Pertiwi WE, Karmila K. Determinan Personal Hygiene pada Siswa-Siswi Asrama. Jurnal Ilmu Kesehatan Masyarakat. 2020;9(04):239-47.

7. Pakasi DT, Kartikawati R. Antara Kebutuhan dan Tabu: Pendidikan Seksualitas dan Kesehatan Reproduksi Bagi Remaja di SMA. Jurnal Makara Seri Kesehatan. 2013;17(2):7987.

8. Yulianti. Efektivitas Penerapan Kurikulum Tingkat Satuan Pendidikan (Ktsp) Terhadap Proses Pembelajaran Aqidah Akhlak Kelas V Di Madrasah Ibtidaiyah Raudlatul Falah Kebagusan Pasar Minggu. 2013;

9. Sugiyono 20. Metode Penelitian Kuantitatif, Kualitatif dan R \& D. Bandung: CV. Alfabeta; 2017.

10. Ami, Kamila, Fatiah Handayani dan Nurhayati. Buku Rancangan Kurikulum Pendidikan Kesehatan Reproduksi Remaja Berbasis Kasus. Sekolah Tinggi Ilmu Kesehatan 'Aisyiyah Bandung; 2020.

11. Nurhayati, Handayani F, Kamila A. Implementation of Adolescent Reproductive Health Policies in Bandung District BT - 1st International Conference on Science, Health, Economics, Education and Technology (ICoSHEET 2019). In Atlantis Press; 2020. p. 148-52. Available from: https://doi.org/10.2991/ahsr.k.200723.037

12. Caswell HL, Campbell DS. Curriculum development. American Book Company; 1935.

13. Sanjaya W. Kurikulum dan Pembelajaran. 6th 
ed. Jakarta: Prenadamedia Group; 2015.

14. Saputra PA, Yanuarita P. Hubungan Fasilitas Belajar dan Motivasi Belajar terhadap Hasil Belajar IPS Siswa Kelas V. Joyf Learn J. 2017;6(1):40.

15. Republik Indonesia. Peraturan Pemerintah Republik Indonesia Nomor 61 Tahun 2014 Tentang Kesehatan Reproduksi.

16. Lubana L, Prasetyo APB, Cahyono E. Pengembangan Perangkat Pembelajaran Biologi Berbasis Kasus dan Berorientasi Pendidikan Karakter. Journal of Innovative Science Education. 2013;2(1).

17. Jin J, Bridges SM. Educational technologies in problem-based learning in health sciences education: a systematic review. Journal of Medical Internet Research. 2014 Dec;16(12):e251.

18. Faisal R, Bahadur S, Shinwari L. Problem-based learning in comparison with lecture-based learning among medical students. The Journal of the Pakistan Medical Association. 2016 Jun;66(6):650-3.
19. Kurniaman O, Lazim N. Implementasi Kurikulum 2013 di Kelas II SD Negeri 079 Pekan Baru. Tunas Bangsa Journal. 2017;4(2):185-97.

20. Nawali AK. Dampak Penerapan Kurikulum Kementerian Agama dan Kurikulum Pesantren Terhadap Peningkatan Hasil Belajar PAI di MAN YOGYAKARTA. Al-Ikhtibar J Ilmu Pendidik. 2018;5(1):555-75.

21. Magdalena I, Pranidana W, Ummah N, Aziah SR. Analisis Penerapan Kurikulum 2013 terhadap Hasil Belajar IPS Kelas V di MI Al-Fitroh. J Halaqah [Internet]. 2020 Jan 31;2(1 SE-Articles). Available from: http:/ejournal.pamaaksara.org/index.php/hal/ar ticle/view/85

22. Albaar MR. Desain Pembelajaran Untuk Menjadi Pendidik yang Profesional. Ponorogo: Uwais Inspirasi Indonesia; 2020.

23. Stufflebeam DL, Coryn C. Daniel Stufflebeam's CIPP model for evaluation: An improvement and acountability-oriented aproach. Someset: Jossay-Bass. 2014. 